Meta

Journal des traducteurs

Translators' Journal

\title{
Towards a Psycholinguistic Profile of the Interpreter
}

\section{André Brisau, Rita Godijns et Chris Meuleman}

Volume 39, numéro 1, mars 1994

La traduction et l'interprétation dans la Belgique multilingue

URI : https://id.erudit.org/iderudit/002147ar

DOI : https://doi.org/10.7202/002147ar

Aller au sommaire du numéro

Éditeur(s)

Les Presses de l'Université de Montréal

ISSN

0026-0452 (imprimé)

1492-1421 (numérique)

Découvrir la revue

Citer cet article

Brisau, A., Godijns, R. \& Meuleman, C. (1994). Towards a Psycholinguistic Profile of the Interpreter. Meta, 39(1), 87-94. https://doi.org/10.7202/002147ar

\section{Résumé de l'article}

Dans cet article on tente de démontrer qu'il existe un rapport important entre les facteurs cognitifs / affectifs et le processus d'interprétation. Le but de cette démonstration est de pouvoir établir un profil psycholinguistique de l'interprète. Pour ce faire, on décrira et expliquera les différents paramètres qui déterminent le processus d'interprétation et leurs liens avec, ce qui sera, le profil psycholinguistique de l'interprète.
Tous droits réservés (C) Les Presses de l'Université de Montréal, 1994
Ce document est protégé par la loi sur le droit d'auteur. L'utilisation des services d'Érudit (y compris la reproduction) est assujettie à sa politique d'utilisation que vous pouvez consulter en ligne.

https://apropos.erudit.org/fr/usagers/politique-dutilisation/ 


\title{
TOWARDS A PSYCHOLINGUISTIC PROFILE OF THE INTERPRETER
}

\author{
ANDRÉ BRISAU, RITA GODIJNS AND CHRIS MEULEMAN \\ Provinciale Hogeschool voor Vertalers en Tolken, Ghent, Belgium
}

\begin{abstract}
Résumé
Dans cet article on tente de démontrer qu'il existe un rapport important entre les facteurs cognitifs / affectifs et le processus d'interprétation. Le but de cette démonstration est de pouvoir établir un profil psycholinguistique de l'interprète. Pour ce faire, on décrira et expliquera les différents paramètres qui déterminent le processus d'interprétation et leurs liens avec, ce qui sera, le profil psycholinguistique de l'interprète.
\end{abstract}

\section{INTRODUCTION}

The abilities and skills required of an interpreter have for some time been the subject of research in various disciplines. Indeed, ever since the disciplines of linguistics and psychology joined forces in this field, probably for the first time at the 1977 symposium on language, interpretation and communication (Gerver and Sinaiko 1978), linguistic, psycho-affective, neurolinguistic as well as what might conveniently be termed heuristic approaches to interpretation have been adopted. It is probably this very variety of the avenues by which aspects of interpreting have been approached that has led to the somewhat bewildering picture now before us.

Since the study of interpreting can be said to be in its early stages, it stands to reason that it is hard to find explicit, hard-and-fast rules about what the process of interpretation involves, although the precepts of professional interpreters, formulated in the years when conference interpreting began to be widely recognized, remain as valid as ever. It comes as no surprise, therefore, that a very recent survey of screening tests for interpreters-to-be (Lambert 1991: 593-594) concludes by pointing out the necessity of verifying an "impression" and gathering "sufficient data over the next few years".

The present paper describes the preliminary basis for a project currently in progress at the College for Translators and Interpreters in Ghent, Belgium. The starting point of the project is the fact that most language learning approaches in general, and interpreter training programmes in particular, appear to disregard the learner as a human being and neglect the psychoaffective framework he brings to the task of learning a language. Since we believe the links between cognitive/affective factors and interpreting skills to be exceedingly strong, as we will attempt to show, our project aims at offering a psycholinguistic profile of trainees in interpretation, thus applying recent research in applied linguistics, psychology and neurolinguistics, specifically in the field of second language acquisition. This profile will then serve as the basis for a highly focused training programme, which centres not only on mere language mastery or practical interpreting skills but also on the interpreter as a person trying to achieve an outstanding command of at least three languages.

It follows that we will first have to attempt to identify the parameters that determine the interpreting process. In the picture thus emerging, we feel a distinction will have to be made between linguistic and non-linguistic parameters operating alternatively at the input 
and output levels. At the linguistic level we will have to deal with vocabulary, its acquisition and use, syntax, listening comprehension and delivery issues. At the non-linguistic level we find psycho-affective elements such as motivation and attitude, (meta)cognitive style, anxiety, stress resistance, real-world knowledge and, last but certainly not least, the self concept; at the neurolinguistic level, elements such as attention, memory and cerebral lateralization. We cannot, within the scope of this article, proceed to an in-depth analysis of each of these parameters, the list of which may not even be exhaustive. We will, however, attempt to pinpoint the most salient features of the various parameters and their links with what will eventually have to become an interpreter's psycholinguistic profile.

\section{PARAMETER SURVEY}

\section{Linguistic Factors}

Vocabulary

We believe the interpreter will, very consciously, have to make a firm distinction between various types of vocabulary in trying to solve his need for "words". First he will have to curb a language student's innate craving for synonyms, because such an urge will tie him down to a paradigmatic search for words. He will have to actively constitute "word-baskets", filled with (idiosyncratic or other) word or image associations enabling him to convey the message at all costs, perhaps even at the cost of not using the "exact" word. The inferences on which the baskets will be set up will stretch across the different languages the interpreter is using (e.g. cintrage de buses, cintré, hips, tailored shirts, curbs > tube bending). Secondly there is what one might call a "pre-technical vocabulary", a vocabulary with a degree of technicity but not indulging in any jargon or hermetism (e.g. nitrogen, vocational training, arc welding). These two types of vocabulary must be part of the interpreter's active assets.

Finally there is the subject-linked, jargonistic vocabulary the interpreter must be able to absorb at very short notice (e.g. quench towers, martensite matrix, FILO fire). This is a vocabulary deletable from memory as soon as "the job" is over, unless a second and a third interpreting job deal with the same subject and so cause the vocabulary to move to the "pre-technical" level.

The would-be interpreter can be taught to make this kind of distinction and to hunt in the first place for the cement-like basket words rather than for the superspecialized, once-in-a-lifetime technical terms. He will also have to be taught how to rummage in his baskets, how to make them tumble and spill their contents, enabling him to browse through their contents in his search for the word that will allow him to complete a message while lacking the "correct" translation for some word or other.

\section{Syntax}

Obviously an interpreter will have to be able to do more than just put together wellendowed baskets of associated vocabulary items. He will have to be able to put them in a correctly constructed sentence. Probably more than those working in any other discipline, the interpreter will have to provide proof of major flexibility. He will have to be an accomplished syntactic "juggler", able to start a sentence with any phrase or even word that belongs in that sentence (making subject into object and vice versa, putting adjuncts in front or in midposition, or making a subject out of what the adjuncts say, etc.), able to bifurcate a sentence or steer it in a direction other than that originally intended, able to put ideas in a positive or negative mould (white being non-black and yes being non-no), able to 'shunt' his way around word obstacles rather than stop and contemplate ways of solving the problem - a far cry from the orthodox grammarian's approach to language 
learning but rather close to the way any dyed-in-the-wool interpreter goes about his task in the solitude of his booth. Which, to be sure, does not mean an interpreter should pay no attention to grammatical accuracy, but, as we have just pointed out, there must be more...

\section{Listening Comprehension}

Phonological, morphological and syntactic patterns have to be recognized instantaneously. This requires the listener to resort to his knowledge of the source language. Interesting insights into the process of listening in order to comprehend a text are provided by Anderson (1983), who distinguishes three interrelated processes: perceptual processing, parsing and utilization. He shows that a listener's first task is to draw on his linguistic skill: signals such as pauses and acoustic emphases will help to achieve a primary level of segmentation. That level will then be complemented by detecting individual words and matching their aural pattern with the representation of that word in the listener's memory. By way of a body of grammatical (morphological and syntactic) rules, individual word meanings will then be established.

It must be noted from the very outset, however, that before these individual word meanings can be linked to form chunks of information (or units of meaning), two other parameters will vie for attention: cognitive style and real-world knowledge. Any wouldbe interpreter with too analytical an approach to the decoding problem, i.e. one who sticks to isolated words or phrases, will be stymied by temporary problems of incomprehension, and will be prevented from simply moving on to other elements in the sentence in an attempt to make sense of the message. Or he will find it hard to call upon any real-world knowledge at his disposal which might enable him to come up with a workable picture or Gestalt. These two elements, being non-linguistic, will be dealt with briefly below.

Lambert (1991: 589) has pointed out the significance of cloze tests as a screening tool, both for determining a candidate's command of the B language and for examining his ability to keep informed of current affairs. The scope of these exercises could be broadened so that they may be used in the early stages of training, for instance, as anticipation exercises based not only on expectancy grammar but also on "expectancy terminology" (as in Free trade is based on the free ... of goods and services) and "expectancy content" (as in The EC member states will not find it easy to meet the budgetary norms laid down in the ...).

Delivery

Pronunciation and enunciation are not discussed extensively in the literature on the interpreter's abilities. They are clearly thought of as components of his skill which can easily be distinguished from others and exercised separately. Although this is true, it is worth emphasizing that both have an important psychological foundation.

In putting forward their theory of language ego, Guiora and Schonberger (1990) use pronunciation as a criterion which provides us with, among other things, a measure of a subject's willingness to identify with the foreign language he is learning and the culture represented by that language. The importance of this factor has been highlighted in other studies on motivation and attitude (Gardner 1985). Evidently, aversion to a language or its culture may be a barrier to acquiring a native-like pronunciation. For interpreters expected to work only towards their mother tongue (A-language), this factor may not be of crucial importance. Nevertheless, the question remains whether (subconsciously) ignoring the pronunciation of the $\mathrm{B}$-language does not also constitute an obstacle to listening comprehension, particularly if that B-language accepts regional varieties on an equal footing with the standard pronunciation. For interpreters who work in another kind of market, one which requires them to translate into one or even two B-languages, it will be of the utmost importance to acquire near-native mastery of the pronunciation of his B-language(s). 
The interpreter will have to prove he is capable of shedding his mother tongue ego and switching to a B-ego, posing as a Briton, a Frenchman, etc.

Enunciation often presents difficulties even for native speakers. General voice quality is considered a major factor in the selection process outlined by Lambert (1991: 593). It is clear that in an extensive training programme, and certainly in a curriculum spread over more than one academic year, speech training can be included with good results. The psychological causes underlying speech defects are, of course, a different matter altogether.

\section{Psycho-affective Factors}

\section{Self Concept}

At the basis of our research into non-linguistic parameters operating on an interpreter's potential, we find the self concept, i.e. the concept a future interpreter has of himself as a person, as a foreign-language learner, as an academic. The interpreter's ideas about what he thinks he is, what he would like to be and what he thinks other people believe him to be, and any discrepancies between these three concepts which have evolved during his developmental process, will have a bearing upon his performance. The self concept idea as developed by researchers as early as James (1890) was integrated into the Gardner socioeducational model (1985) by Laine (1987), and its relevance to foreign language teaching was proved following a LISREL factor analysis. A modified version of the Laine self concept model adapted to the Belgian setting has been tested in the five Colleges for Interpreters and Translators (first-year students with French as one of their foreign languages) in the Flemish-speaking part of Belgium (Meuleman, forthcoming).

\section{Cognitive Style}

However much debated and contested the existence of a cognitive style may be (Witkin et al. 1979; Chapelle 1992; and others), it remains a heuristically acceptable and intuitively valid tool, which in our view only awaits further exploration and scaffolding. A basic distinction, relevant to our research, is that between "top-down" and "bottom-up" processing (Witkin et al. 1979; Anderson 1983).

The latter is to be compared with the word-for-word translation that outsiders often think interpreting is. It is used by individuals who analyse each individual word, looking for its meaning or grammatical characteristics and then simply adding up these meanings. The inefficiency to which this type of processing leads are echoed in the mistakes produced by literal translation: the meaning of any word depends on its context, and words therefore cannot be analysed (translated) in isolation; the context is used to narrow down the range of possible meanings, and the more context is provided; the more quickly the correct meaning is established (the faster the interpreter understands the sense of an utterance); finally, bottom-up processing, analytical as it is, does not allow one to make predictions about intersentential and outer-text meaning and so slows down comprehension (the interpreter cannot anticipate and is thus left without a powerful tool).

The basis of a cognitive-style training element will probably be a conscious alternation between, on the one hand, a holistic, Gestalt-like approach to a message, in which the trainee is taught to make do with whatever intelligible message-building blocks he can come up with, and, on the other, an analytical approach allowing the student to impose his schemata on the message in an attempt to comprehend.

\section{Real-world Knowledge}

The interpreter will have to be taught to call upon any source of knowledge he takes to the task of interpreting and not limit his efforts to conjuring up linguistic props. If a word is to be allocated its correct meaning from the several meanings that may be stored 
in the listener's long-term memory (movement is different in a quick movement of the hand and the free movement of goods and services), the context must be called into play and the listener will proceed to a parallel distributive search. The individual's ability to move back and forth between his linguistic understanding and his extra-linguistic knowledge is fundamental to the interpreter's task.

\section{Anxiety}

As is the case with many a concept in the affective framework, no general consensus can be found on the impact of anxiety in its various and varied forms (general, trait, state, test, facilitating and debilitating, situational, communicative) on language acquisition. All in all, researchers (McIntyre and Gardner 1991; Horwitz et al. 1986) and, not least, educationists in the field agree, however, that anxiety is a factor to be reckoned with. To the interpreter the distinction between debilitating and facilitating anxiety will be of the utmost importance, as he will have to deal with the butterflies that will undoubtedly hover inside him at any moment. Awareness of such feelings and of the important potential of the "positive frustration" they may give rise to will be an element of training.

\section{Attitude}

As shown by recent motivational and attitudinal research undertaken by Gardner (1985), Clement and Kruidenier (1983), Laine (1987) and others, there is a definite link between motivation and attitude toward a language, its community, the teacher and the teaching situation on the one hand and achievement on the other. This means attitude is a factor to be taken seriously and to be acted upon. Any interpreter training programme should, for instance, aim at fostering an intimate link between the candidate and the language or the language "environment" in the broadest sense of the word. "Love thy language" should be part of the teaching message.

\section{Stress Resistance}

No programme can afford to disregard the tremendous stress interpreting can sometimes put upon an individual. One should consequently be able to gradually build up sufficient resistance to be able to cope with the effort of interpreting for a minimum period of thirty minutes, preferably for a longer stretch of time, just to be on the safe side.

\section{Metacognition}

A final observation has to be made with regard to metacognition and metacognitive strategy teaching. As generally speaking we are dealing with both intelligent and motivated students, there is a tremendous know-how waiting for the trainer to plug into. It is of the utmost importance for the trainer to establish a rapport with his student-interpreters at the metacognitive level, explaining one thing and another about the workings of language, language acquisition, memory, etc., allowing the student to get a firmer grasp on his learning process, to control and monitor his efforts and remain in tune with his (language) personality structure. This approach, of course, can hardly be said to be for interpreters alone, but since students who opt for interpretation courses might be expected to have stronger than average motivation ...

\section{Neurolinguistic Factors}

Attention

The function of attention, together with that of memory (discussed below), is the thread binding together most of the interpreter's skills mentioned so far. These are very complex functions, with regard both to the brain mechanisms which enable them to operate 
and to the theoretical framework in which the various aspects of attention and memory are to be placed.

The biological background of these functions is of no concern in the present context, while the theoretical framework underlying their neurophysiological operation is of great relevance. Posner and Boies (1971) distinguish three aspects in the system of attention: alertness, selectivity or targeted attention, and shared attention or information processing capacity. Alertness refers to a state of consciousness affecting a person's general susceptibility to stimulation. It is not constant and fluctuates with time. Not all stimuli to which we are subjected are processed; the "cocktail party phenomenon" illustrates our capacity for selecting stimuli. Shiffrin and Schneider (1977) describe a model of selective capacity, showing that learning processes can, to a large extent, automatize the processing of great amounts of information, so that automatic responses are generated. As a result, one can target one's attention and choose what information will be consciously processed, according to requirements. In many situations it is necessary to spread one's attention over several sources of information. However, as an information-processing system, man has his limitations: in a given time span he can assimilate only a limited quantity of simultaneously presented information. The rate at which he will do so, and the time at his disposal, will determine how successful he will be at sharing his attention.

Clearly, the function of attention as a whole will have to work efficiently if the interpreter is to cope adequately. If he commands a high degree of automatic language processing, his (outstanding) capacity for selective attention can be reserved for the more complex demands of his work. In dealing with these, the interpreter will probably have to divide his attention over a number of sub-tasks for which different skills need to be addressed: listening, understanding, reformulating in another language, all at considerable speed.

\section{Memory}

Attention and memory are closely linked. There can be no memory without attention, since a particular level of consciousness is needed for information to gain access to memory. Conversely, there can be no attention without memory, since for conscious processing (i.e. selecting the appropriate stimuli) we rely on our memory to provide us with experiences acquired through learning.

The function of attention is therefore the first memory mechanism, that of the immediate memory. It is tied up with the mode (visual, tactile, auditory) in which information is obtained. It is obvious that in an interpreter it is the auditory immediate memory which needs to be strongly developed. The short-term memory can store information for periods ranging from a few seconds up to a few minutes, thanks to electrical activity in Papez' circuit. Its importance for listening comprehension and vocabulary, for example, was pointed out above. Information stored in the short-term memory can be transferred to the long-term memory, where it can remain for anything between a few hours and several years. This is a memory with a huge capacity, based on biochemical processes. Once again, a properly functioning long-term memory is indispensable to the interpreter, for it has to store a broad general knowledge and a thorough command of language.

\section{Cerebral Lateralization}

Since P. Broca discovered the importance of the left hemisphere for the acquisition of language, our understanding of the role played by the left and right hemispheres has been greatly refined. Research has been carried out into the question of hemispheric involvement in bilingualism, multilingualism and interpretation (Fabbro et al. 1990 and others). So far, no unequivocal answer has been given. Indeed, the hemisphere in which 
processing of a first, second or third language is carried out is influenced by quite a large number of factors, e.g. the age at which a language has been acquired. Even a person's hand preference or his cognitive style may be related to his language lateralization.

In drawing up an interpreter's psycholinguistic profile, it will probably be rewarding to study and compare lateralization in interpreters and in bilingual or multilingual people. To this end, the non-invasive dichotic listening test can be used to study hemisphere-related representation of spoken language (Godijns 1985).

\section{CONCLUSION}

The aim of the present article was to set the guidelines for future research such as that planned by the authors, and to establish its objectives.

In a first stage the hypothesized parameters will be examined in all third-year students at PHVT (20-to-21-year-old students who, at the outset of the academic year, have not yet made a choice between translator and interpreter training). The self concept, attitude, motivation and anxiety parameters will be explored by means of a questionnaire, both focusing on a theoretical self concept model and delving into specific interpreter characteristics; some of the other parameters will be studied via existing tests (memory tests, concentration span tests, dichotic listening tests, Wechsler, anxiometer, GEFT, etc.). The same profile will also be examined in students who have just completed the fourth year (i.e. students who have gone through the two-year interpreter training programme). A comparison of these results will enable us to proceed to a first discriminatory analysis of the proposed profile. Needless to say, the results of repeated testing can be expected to yield useful data for a new approach to an interpreter training programme.

It is understood that these objectives may be deemed ambitious; however, it is believed that a thorough analysis of the parameters determining interpretation as a language operation and of the would-be interpreter as the person willing to undertake such an endeavour is the only key to exploring the inner workings of interpreting.

\section{REFERENCES}

ANDERSON, J. R. (1983): The Architecture of Cognition, Cambridge, Mass., Harvard University Press.

CHAPELLE, Carol A. (1992): "Disembedding 'Disembedded Figures in the Landscape ...': An Appraisal of Griffith and Sheen's Reappraisal of L2 Research on Field Dependence/Independence", Applied Linguistics, 13-4, pp. 375-384.

CLEMENT, R. and B. G. KRUIDENIER (1983): "Motivational Variables in Second Language Acquisition: a study of francophones learning English", Canadian Journal of Behavioral Science, 9, 205-215.

FABBRO, F., GRAN, L., BASSO, G. and A. BAVA (1990): "Cerebral Lateralization in Simultaneous Interpretation", Brain and Language, 39-1, pp. 69-89.

GARDNER, R. C. (1985): Sacial Psychology and Second Language Learning: the Role of Attitudes and Motivation, London, Edward Arnold.

GERVER, David and Wallace H. SINAIKO (Eds.) (1978): Language, Interpretation and Communication, New York, Plenum Press.

GODIJNS, R. (1985): "Conditions posées à un test d'écoute dichotique", in Spoelders, M. et al., Eds., Language, Acquisition and Learning. Essays in Educational Pragmatics II, Leuven, Acco, pp. 193-206.

GUIORA, A. Z. and R. SCHONBERGER (1990): "Native Pronunciation of Bilinguals", in Leather J. and James A., Eds., New Sounds 90. Proceedings of the 1990 Amsterdam Symposium on the Acquisition of SecondLanguage Speech, University of Amsterdam, pp. 1-15.

HORWITZ E., HORWITZ M. B. and J. COPE (1986): "Foreign Classroom Anxiety", The Modern Language Journal, 2, 125-132.

JAMES, W. (1890): Principles of Psychology, New York, Holt, Rinehart and Winston

LAINE, E. (1987): Affective Factors in Foreign Language Learning and Teaching: a Study of the Filter, Report $I$ and II, Unpublished $\mathrm{PhD}$, University of Jyväskylä, Finland.

LAMBERT, Sylvie (1991): "Aptitude Testing for Simultaneous Interpretation at the University of Ottawa", META, 36-4, pp. 586-594. 
MACINTYRE, P. D. and R. C. GARDNER (1991): "Language Anxiety: its Relationship to other Anxieties and to Processing in Native and Second Language", Language Learning, 41-4, pp. 513-534.

MEULEMAN, Chris (forthcoming): Predictors for Differential Language Outcomes, $\mathrm{PhD}$, University of Ghent, Belgium.

POSNER, M. I., and S. J. BOIES (1971): "Components of Attention", Psychological Review, 78, pp. 391-408.

SHIFFRIN, R. M. and W. SCHNEIDER (1977): "Controlled and Automatic Human Information Processing: II, Perceptual Learning, Automatic Attending and a General Theory", Psychological Review, 84, pp. 127-190.

WITKIN, H., GOODENOUGH, D. R. and P. K. OLTMAN (1979): "Psychological Differentiation: Current Status", Journal of Personality and Social Psychology, 37-7, pp. 1127-1145. 